\title{
Study on Clogging Problem of Drip Irrigation Systems and its Remedies
}

\author{
Avishek Shaw*, Uddipta Ghosh and Ranajit Kumar Biswas \\ Department of Soil and Water Engineering, Bidhan Chandra Krishi Viswavidyalaya, \\ Mohanpur, Nadia, West Bengal-741252, India \\ *Corresponding author
}

\begin{tabular}{|l|}
\hline Ke y w o r d s \\
Surface, Sub- \\
surface drip, \\
clogging, Emitters, \\
Discharge, \\
Chlorination, \\
Improvement \\
\hline Article Info \\
\hline Accepted: \\
12 July 2018 \\
Available Online: \\
10 August 2018 \\
\hline
\end{tabular}

A B S T R A C T

The water conservation is vital to maintain agricultural production in areas of small rainfall or jagged rain sharing. Under this situation, surface and Sub-surface drip irrigation may play a momentous role in overcoming the paucity of water and economic production of vegetable crops, particularly in water shortage areas. Drip irrigation is the most efficient slow, even application of low-pressure water to soil and plants using plastic tubing placed near the plants' root zone. But Clogging is one of the most important problems encountered in this irrigation system which significantly reduce the efficiency of the system which consequently may encounter severe economical consequences in terms of the system operation, maintenance and the ultimate goal for sustainable crop production. The experiment was conducted at the Soil and Water Engineering Laboratory under the Faculty of Agricultural Engineering, Bidhan Chandra Krishi Viswavidyalaya, Nadia, West Bengal during the period of 2015-16. The lateral contained 94 emitters of nominal discharge 4.0lph. However, the newly used emitters gave the average discharge of $4.18 \mathrm{lph}$ at $1.05 \mathrm{~kg} / \mathrm{cm}^{2}$ pressure. The emitters were nonstop operated for 29 days and the reduction of discharges for clogging for each and every emitter was determined at 0, 8, 15 and 29 days interval. Chlorination was performed by injecting bleaching powder in a $300 \mathrm{ml}$ of water for 30 minutes. After performing chlorination, the discharges were measured at 1, 3, 6 and 9 days interval to evaluate the performance of chlorination on clogging. The improvements of discharges of the emitters were found about 14 and $23 \%$ in 3 and 6 days respectively after chlorination. It was also found that there is no improvement of chlorination after 6 days.

\section{Introduction}

India has one of the largest irrigated areas in the world, but its per-capita as well perhectare availability of water is one of the lowest in the world. The efficient and judicious use of both water and fertilizer is the key for improving agricultural production and productivity in the country (Ghosh et al.,
2018). Owing to various reasons the demand for water for different purposes has been continuously increasing in India, but the potential water available for future use has been declining at a faster rate (Saleth, 1996; CWC, 2005). The agricultural sector (irrigation), which currently consumes over 80 percent of the available water in India, continues to be the major water-consuming 
sector due to the intensification of agriculture (Saleth, 1996; MoWR, 1999; Iyer, 2003). Due to water scarcity, the available water resources should be utilized very effectively through water saving irrigation technologies to maximize the yield. Furrow and basin irrigation methods are commonly adopted to irrigate the crop, which causes adverse effects of water excess and water stress (Hedge and Srinivas, 1990; Raina et al., 2011). Drip irrigation is the most efficient and new technology of irrigation in India to supply precise amounts of water directly into the vicinity of root zone at right time, matching with the consumptive water demand of plant for optimum growth, improved yield and quality of produce with substantial water saving (Kumar et al., 2005; Shashidhara et al., 2007; Thangaselvabai et al., 2009). The drip method of irrigation also helps in reducing over-exploitation of groundwater that partly occurs in surface irrigation. Water saving through drip irrigation system is estimated to be in the range of 12-84 per cent in different crops, besides its beneficial impact on crop yields (Narayanamoorthy, 1996; 1997). Drip irrigation refers to frequent application of small quantities of water on or below the soil surface as drops. It embodies the philosophy of irrigating the root zone instead of entire land. The drip fertigation method has considerable potential to improve water and fertilizer use efficiency.

Clogging of emitters has been a major problem in drip-line systems because of the high levels of suspended solids and nutrients associated with water. Research indicates that the cause of clogging in drip irrigation systems fall into three main categories: (1) physical, caused by suspended solids; (2) chemical, caused by precipitation reactions; and (3) biological, caused by bacterial and algal growth (Bucks et al., 1979).The problem of clogging may occur even when all of the factors relating to emitter are suitable for a uniform water distribution. In micro-irrigation systems that are characterized by a number of emitters with narrow nozzles, irrigation uniformity can be spoilt by the clogging of the nozzles with particles of chemical character (Oron et al., 1979; Merriam and Keller, 1978; English, 1985; Capra and Scicolone, 1998). Emitter clogging is directly related to irrigation water quality, which appears a function of the amount of suspended solids, chemical constituents of water and micro-organism activities in water (Gilbert and Ford, 1986). Therefore the mentioned factors have a strong influence on the precautions that will be taken for preventing the plugging of the emitters.

During irrigation some clogs due to microorganism activities take place in cases when wastewater is used (Ravina et al., 1997; Ould et al., 2007). In locations where the amount of the ingredients as dissolved calcium, bicarbonate, iron, manganese and magnesium are excessive in irrigation water, the emitters are clogged by the precipitation of these solutes (Gilbert and Ford, 1986; Hills et al., 1989). Thin materials like silt, clay and organic matter suspending in quite narrowing emitter outlet due to the precipitation, accelerate clogging by means of piling up easily. This kind of plugging can widely appear in drip irrigation systems in which ground water or surface water rich in minerals is used for irrigation purposes. Hereunder the emitter clogging is directly related irrigation water quality, in other words the amount of suspending clay, chemical constituents and biological activities.

With the above in view, this study was carried out with aim to determine the quality of irrigation water, the level of clogging in different operation period and the performance of different treatment of removal of clogging. 


\section{Materials and Methods}

The study was conducted at the Laboratory of Soil and Water Engineering Department, Faculty of Agricultural Engineering, BCKV, Nadia, West Bengal during the period of 2015-16. One litre plastic water bottles were used to collect the water sample from the laboratory tap. The bottle was completely filled with water to avoid air inside the bottle. The cap of the bottle was firmly closed and stored in a clean place in the lab. The samples were analyzed for physico-chemical and biological properties at the Water Analysis Laboratory of Department of Soil \& Water Conservation of Bidhan Chandra Krishi Viswavidyalaya. The quality of irrigation water was compared to different physiochemical properties following Nakayama and Bucks (1991) and Capra and Scicolone (1998).

\section{Experimental set-up}

The drip irrigation set-up consisted of a lateral of diameter $10 \mathrm{~mm}$ with 94 numbers of emitters on it at $0.5 \mathrm{~m}$ regular interval. The emitters were of nominal discharge rate of 4 lph. The set up was connected with a lab tap for supply of water. The pressure at the head end of the laterals was monitored continuously by using a pressure gauge. Almost steady discharge was maintained by keeping the pressure constant at $1.05 \mathrm{~kg} / \mathrm{cm}^{2}$ with regulating the tap bib-cock and thereby the flow of water in the set-up. The set-up did not have any filter to screen the foreign material in water.

The emitters in the lateral were marked by numbers 1 to 94 from the tail end. At steady pressure the discharges of the emitters were measured by collecting the dripped water in the measuring cylinder for a period of 5 minutes to convert it to discharges in litre/hour. The discharges were recorded for
$0,7,15$ and 30 days at $12 \mathrm{pm}$ after initiation of experimentation. The system was run continuously during these 30 days of experimentation without any interruption.

\section{Parameters}

From the experiment we have taken the parameter of average discharge rate emitter, mean discharge ratio, standard deviation, coefficient of variation of emitter flow, uniformity of water application, reduction of mean discharge in percentage and the percentage of completely clogged emitters.

\section{Treatment of clogged emitters}

As a treatment of this biological growth chlorination was done by using the bleaching powder at a concentration of $40 \mathrm{mg}$ in $600 \mathrm{ml}$ water to inject it in drip system in 30 minutes with 3 days of interval.

\section{Results and Discussions}

\section{Water quality report}

The irrigation water was analyzed for Electrical Conductivity (EC), pH, Total Suspended Solids (TSS), Total Dissolved Solids (TDS), Total Iron ( $\mathrm{Fe})$, Calcium $(\mathrm{Ca})$, Manganese (Mn), and Bacterial Number (BN). The results have been shown in Table 1.

The quality of irrigation water was found between low to moderate risk in using as drip water in respect of different physio-chemical properties following Nakayama and Bucks (1991) and Capra and Scicolone (1998).

\section{Discharge parameters at certain interval before and after treatment}

Tables 2 and 3 have showed the different parameters of discharge before and after 
applying treatment respectively. From the above results we have found out that the development of clogging to cause $20 \% \mathrm{CV}$ which was considered the acceptable limit of discharges reached on 8 days i.e. 192 hours appears to be inconformity to the quality of water. Further, the $\mathrm{CV}$ of discharges of the new emitters was $10 \%$. The improvement of discharges of the emitters is found about 14 and $23 \%$ in 3 and 6 days respectively after chlorination. It was also found that there was no improvement of chlorination after 6 days. However, the discharge rates remain unaffected up to another 3 days at least after the 6 days (Fig. 1).

Table.1 Irrigation water quality

\begin{tabular}{|c|c|c|c|}
\hline Parameter & Values & \multicolumn{2}{|c|}{ Risk of emitter clogging } \\
\cline { 2 - 4 } & & $\begin{array}{c}\text { Nakayama and } \\
\text { Bucks (1991) }\end{array}$ & $\begin{array}{c}\text { Capra and } \\
\text { Scicolone (1998) }\end{array}$ \\
\hline $\boldsymbol{T S S}(\boldsymbol{\%})$ & Not Detected & & Moderate \\
\hline $\boldsymbol{E} \boldsymbol{C}(\boldsymbol{d} \boldsymbol{S} / \boldsymbol{m})$ & 85 & Moderate & Low \\
\hline $\boldsymbol{p H}$ & 7.66 & Low & Low \\
\hline $\boldsymbol{T D S}(\boldsymbol{m g} / \boldsymbol{L})$ & 544 & Low & Low \\
\hline $\boldsymbol{F e}(\boldsymbol{m g} / \boldsymbol{L})$ & 0.1 & & Low \\
\hline $\boldsymbol{C a}(\boldsymbol{m} \boldsymbol{g} / \boldsymbol{L})$ & 48.4 & Low & \\
\hline $\boldsymbol{M n}(\boldsymbol{m} \boldsymbol{g} / \boldsymbol{L})$ & 0.0004 & & \\
\hline
\end{tabular}

Table.2 Discharge parameters before treatment

\begin{tabular}{|c|c|c|c|c|}
\hline Parameters & 0 Day & 8 Days & 15 Days & 29 Days \\
\hline $\begin{array}{c}\text { Mean Discharge } \\
\text { (1/h) }\end{array}$ & 4.18 & 4.03 & 3.52 & 2.96 \\
\hline $\begin{array}{c}\text { \% Reduction of } \\
\text { mean discharge }\end{array}$ & & 3.58 & 15.78 & 29.18 \\
\hline Standard Deviation & 0.4180 & 0.5642 & 1.1616 & 1.5121 \\
\hline $\begin{array}{c}\text { Coefficient of } \\
\text { variation (\%) }\end{array}$ & 10 & 14 & 33 & 53 \\
\hline $\begin{array}{c}\text { Mean discharge } \\
\text { ratio (Dי\% \%) }\end{array}$ & 100 & 96.5 & 84 & 70.75 \\
\hline $\begin{array}{c}\text { Statistical } \\
\text { uniformity (\%) }\end{array}$ & 90 & 86 & 67 & 49 \\
\hline $\begin{array}{c}\text { Uniformity of water } \\
\text { application }\end{array}$ & 93.37 & 91.12 & 77.46 & 20.21 \\
\hline $\begin{array}{c}\text { Percentage of } \\
\text { completely clogged } \\
\text { emitters }\end{array}$ & 0 & 1.06 & 7.45 & \\
\hline
\end{tabular}


Table.3 Discharge parameters at certain interval after treatment

\begin{tabular}{|c|c|c|c|c|}
\hline Parameters & 0 Day & 3 Days & 6 Days & 9 Days \\
\hline $\begin{array}{c}\text { Mean Discharge } \\
\text { (1/h) }\end{array}$ & 2.92 & 3.34 & 3.6 & 3.6 \\
\hline $\begin{array}{c}\text { \% Reduction of } \\
\text { mean discharge }\end{array}$ & 0 & 14.03 & 23.28 & 23.28 \\
\hline $\begin{array}{c}\text { Standard Deviation } \\
\text { Coefficient of } \\
\text { variation (\%) }\end{array}$ & 1.28 & 1.10 & 1.04 & 1 \\
\hline $\begin{array}{c}\text { Mean discharge } \\
\text { ratio (D) } \text { (5) }\end{array}$ & 100 & 100.03 & 100.18 & 100.12 \\
\hline $\begin{array}{c}\text { Statistical } \\
\text { uniformity (\%) }\end{array}$ & 56.16 & 67.06 & 71.11 & 72.22 \\
\hline $\begin{array}{c}\text { Uniformity of } \\
\text { water application }\end{array}$ & 67 & 76.04 & 78.78 & 80.92 \\
\hline $\begin{array}{c}\text { Percentage of } \\
\text { completely clogged } \\
\text { emitters (Pclog, \%) }\end{array}$ & 11.70 & 5.31 & 4.25 & 4.25 \\
\hline
\end{tabular}

Fig.1 The comparisons of the parameters before and applying chlorination

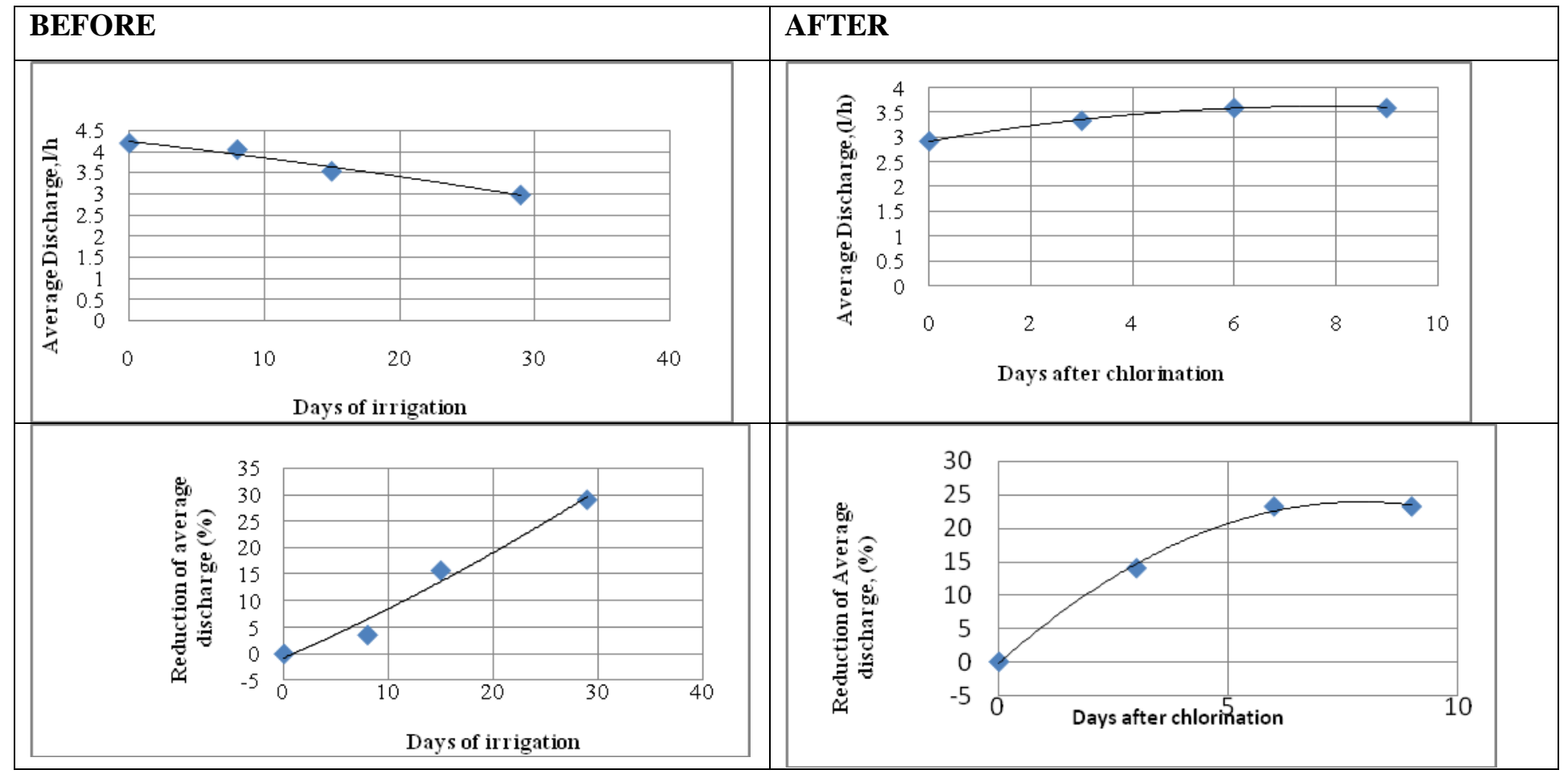




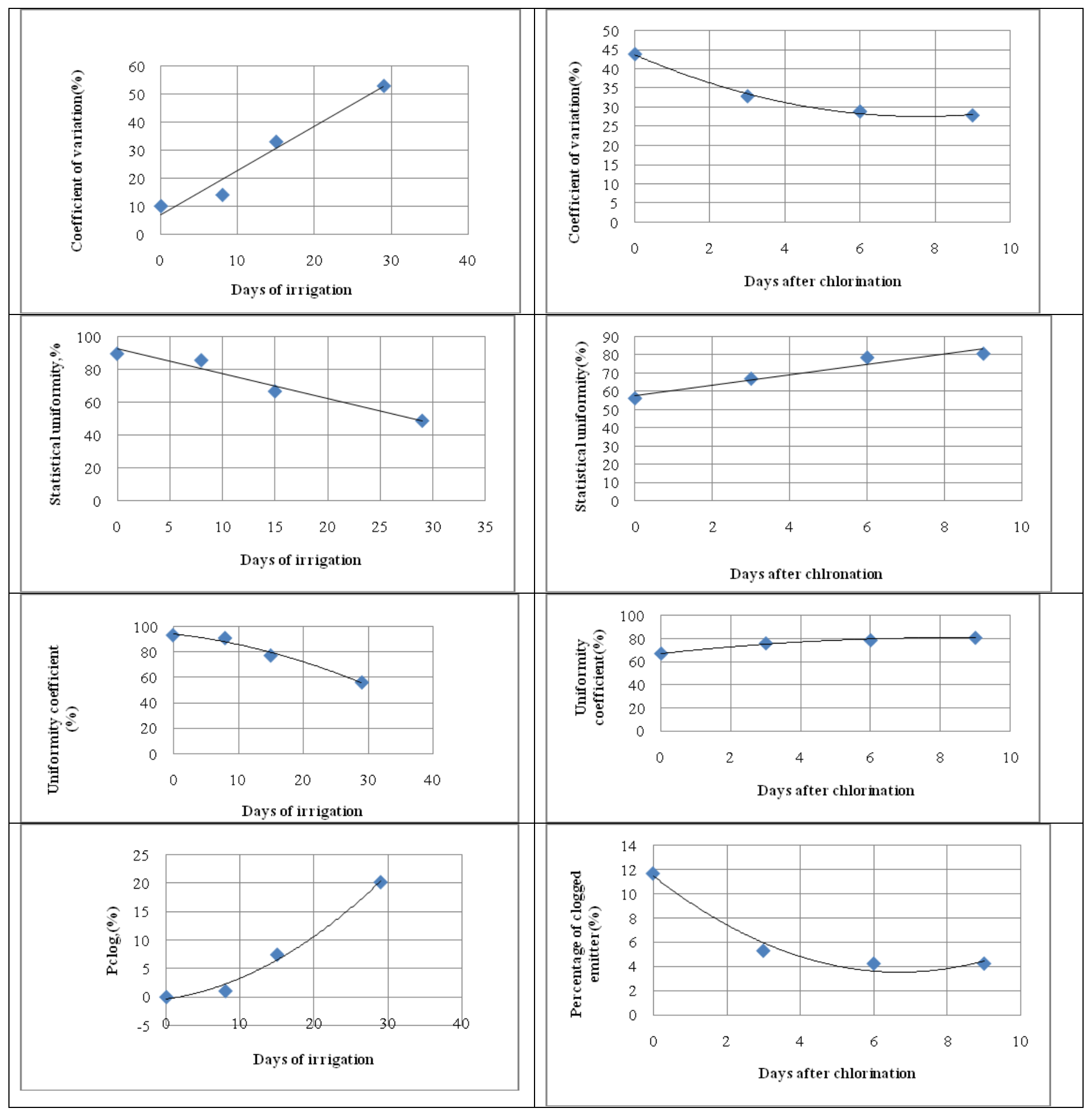




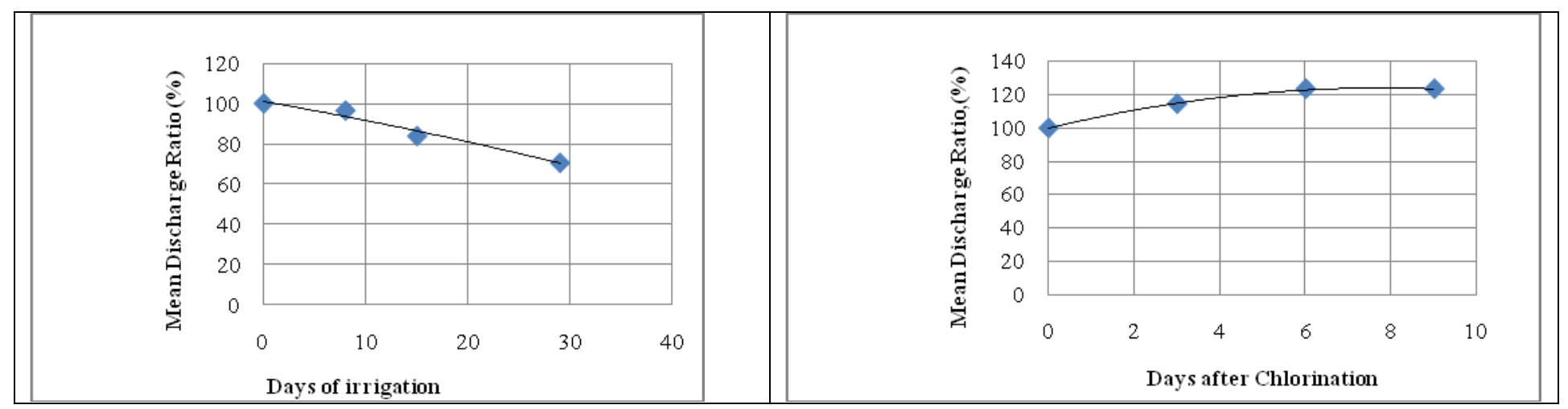

Summary and conclusions are as follows:

The present research work was conducted in the laboratory of Department of Soil and Water Engineering with the aim of examining the quality of irrigation water and its impact on clogging of emitters under drip irrigation. The quality of water was found less to moderate in causing clogging following (Pitts et al., 2003). In overall consideration chlorination may be considered an effective way of treatment of clogging of emitters of drip irrigation system. There are many scopes for the development of the research which can further widen our insight regarding the problems of clogging and its impact on discharge. The pollutant source can be other than chlorinates, such as sulphates, heavy metals, industrial effluents. We can address the issue of application of waste water which can be used as a renewal source or recycling thus reducing the demand of irrigation water demand supplied from the water source. We can check the variability of the coefficient of variation which controls the amount of water to given to the crop. Temperature variation may cause variation in the degree of clogging at the end of the laterals which can cause the variation of discharge as well the pipeline integration systems.

\section{References}

Aujla MS, Thind HS, Buttar GS. (2007). Fruit yield and water use efficiency of eggplant (Solanum melongema L.) as influenced by different quantities of nitrogen and water applied through drip and furrow irrigation. Scientia Horticulturae.; (112):142-148.

Bucks, D.A., Nakayama, F.S. and Gilbert, R.G.,(1979). Trickle irrigation water quality and preventive maintenance. Agricultural Water Management, 2(2), pp.149-162.

Capra A, Scicolone B (1998). Water Quality and Distribution Uniformity in Drip/Trickle Irrigation Systems. $J$. Agric. Eng. Res. 70: 355-365.

CWC. Water and Related Statistics, Ministry of Water Resources, Central Water Commission (CWC), Government of India, New Delhi, 2005.

Dahiwalkar SD, Divekar BK, Sonawane DA.(2004). Relative performance of fertigation on growth, yield and quality of banana. Journal of Maharashtra Agricultural Universities. 29(2): 235-237.

English SD (1985). Filtration and water treatment for micro-irrigation. Drip/Trickle Irrigation In Action. Proceeding of the third international drip/trickle irrigation congress. Nov. 18-21 Fresno, California. 1: 54- 57.

Ghosh, U., Sarkar, N and Biswas, R.K. (2018). A review on performance evaluation of drip irrigation system in banana cultivation. Journal of 
Pharmacognosy and Phytochemistry, 7(1): 866-869.

Gilbert RG, Ford HW (1986). Operational Principles. Developments in Agricultural Engineering 9. Trickle Irrigation for Crop Production Design, Operation and Management. Chap. 3, pp.142-163.

Hedge DM, Srinivas K. (1990). Growth, productivity and water use of banana under drip and basin irrigation in relation to evaporation replenishment. Indian J. Agron., 35(1-2):106-112.

Hills DJ, Navar FM, Waller PM (1989). Effects of chemical clogging on driptape irrigation uniformity. Trans. ASAE 32(4): 1202-1206

Kumar S, Sharma IP, Raina JN.(2005). Effect of levels and application methods of irrigation and mulch materials on strawberry production in north-west Himalayas. J Indian Soc. Soil Sci. 53(1):60-65.

Merriam JL, Keller J (1978). Farm irrigation system evaluation: A Guide for management. Agricultural Irrigation Eng. Dept. Utah State University Logan, Utah, p. 271.

Nakayama, F. S., and D. A. Bucks.(1991). Water quality in drip/trickle irrigations: A review. Irrigation Science 12: 187-192.

Narayanamoorthy A. Beneficial impact of drip irrigation. (1997) A study based on western India. Water Resource Journal. 195:17-25.

Narayanamoorthy A. Evaluation of Drip Irrigation System in Maharashtra, Mimeograph Series No. 42. Gokhale
Institute of Politics and Economics, Pune, 1996.

Oron G, Shelef G, Turzynski B (1979). Trickle irrigation using treated wastewaters. J. Irrig. Drain. Div. 105 (IR2), pp. 175-186.

Ould ABA, Yamamoto T, Fujiyama H, Miyamoto K (2007). Assessment of emitter discharge in microirrigation system as affected by polluted water. Irrigation Drainage Sys. (2007) 21: pp. 97-107.

Pitts DJ, Haman DZ, Smajstrla AG (2003) Causes and prevention of emitter plugging in microirrigation systems. BUL258, Gaines- ville, University of Florida, IFAS, Extension

Ravina I, Paz E, Sofer Z, Marcu A, Schischa A, Sagi G, Yechialy Z, Lev Y (1997). Control of clogging in drip irrigation with stored treated municipal sewage effluent. Agric. Water Manage. 33(1997): 127-137.

Saleth R Maria. Water Institutions in India: Economics, Law and Policy, Commonwealth Publishers, New Delhi, 1996.

Shashidhara KK, Bheemappa A, Hirevekanagoudar LV, Shashidhar K. (2007). Benefits and constraints in adoption of drip irrigation among the plantation crop growers. Karnataka Journal of Agricultural Science. 20(1):82- 84 .

Thangaselvabai T, Suresh S, Prem Joshua J, Sudha KR.(2009).Banana nutrition - A review. Agric. Rev.; 30:24-31.

\section{How to cite this article:}

Avishek Shaw, Uddipta Ghosh and Ranajit Kumar Biswas. 2018. Study on Clogging Problem of Drip Irrigation Systems and its Remedies. Int.J.Curr.Microbiol.App.Sci. 7(08): 1934-1941. doi: https://doi.org/10.20546/ijcmas.2018.708.222 